\title{
Influence of Radioactive Contamination of the Sr-9o Terrestrial Ecosystems on the Enzymatic Activity of the Soil
}

\section{Lavrentyeva G. V. ${ }^{1,2}$, Zaharova V. R. ${ }^{2}$, Mirzeabasov O. A. ${ }^{1}$, and Synzynys B. I. ${ }^{1}$}

${ }^{1}$ Obninsk Institute for Nuclear Power Engineering of the National Research Nuclear University MEPhl, Studgorodok 1, Obninsk, Kaluga region, 249040, Russia

${ }^{2}$ Bauman Moscow State Technical University (Kaluga Branch), Kaluga, Russia

\section{Abstract}

One of the most promising methods of soil diagnostics is the determination of the parameters of enzymatic activity. Changes in urease, invertase, dehydrogenase and catalase activity of soil subjected to radioactive contamination with radionuclide Sr-90 have been studied. When the specific activity of $\mathrm{Sr}-90$ in the soil varies in the range from the control value to more than $1.5 \mathrm{kBq} / \mathrm{kg}$, the stability of invertase, urease and dehydrogenase is established. At the same time, the catalase activity of the soil is a sensitive indicator to radioactive contamination, which is described by a reliable model with a threshold value, after which the oppression of the indicator is observed.

\section{Introduction}

Knowledge $\mathrm{E}$

(c) Lavrentyeva G. V. et al. This article is distributed under the terms of the Creative Commons Attribution License, which permits unrestricted use and redistribution provided that the original author and source are credited.

Selection and Peer-review under the responsibility of the AtomFuture Conference Committee

\section{G OPEN ACCESS}

The soil in the structure of the terrestrial ecosystem is the main depository of pollutants entering the environment, including radionuclides of technogenic origin, which are included in the trophic migration chains and cause irradiation of the ecosystem and human components. Radioactive contamination of soil can disrupt its homeostasis and lead to degradation, which causes a change in the functional and biochemical activity of soil microorganisms. At the same time, over the years, a high efficiency of ecological soil diagnostics has been established through biochemical methods, among which the most promising is the determination of the parameters of enzymatic activity $[2,3,10-$ $12]$.

It should be noted that the level of enzymatic activity of soils can be determined by natural conditions, the physical and chemical properties of soils, as well as contamination of the soil cover of different genesis. At the same time, most of the research is aimed at revealing the stimulation / inhibition of enzymatic activity of soils in conditions of soil contamination with heavy metals, petroleum products, and also with the introduction of mineral substances. However, the question of the effect of ionizing 
radiation on the enzymatic activity of soils under actual conditions remains poorly studied and is mainly aimed at studying the effect of the natural radiation background.

In this paper, we analyze the changes in the invertase, urease, dehydrogenase and catalase activity of soils under conditions of radioactive contamination of the terrestrial ecosystem by the radionuclide Sr-9o.

Catalase - an enzyme that decomposes hydrogen peroxide, the level of which corresponds to the intensity of respiratory metabolism in the soil. Dehydrogenase is a vast group of enzymes of the class of oxidoreductases, which catalyze the elimination of hydrogen from one substrate and its transfer to another. Invertase - splits sucrose into simple sugars - glucose and fructose. Urease is an enzyme of the hydrolase class, it catalyzes the decomposition of urea to ammonia and carbon dioxide.

The experimental site is the territory of the regional storage of radioactive waste. Radioecological situation on the territory is due by Sr-9o [8].

\section{Materials and methods}

Soils were selected on local sites of the studied territory with the help of Edelman's specialized sampler.

Measurement of specific activity with preliminary radiochemical isolation of $\mathrm{Sr}-90$ in samples of soil was carried out on a scintillation beta spectrometer BETA-01C according to the standard procedure for determining Sr-9o content from the beta radiation of its daughter radionuclide Y-90 in environmental objects [4].

Sampling of soil samples and determination of enzymatic activity of soils were carried out according to the generally accepted method [3].

The determination of the enzymatic activity of soils was carried out in triplicate.

The statistical processing of the experimental data was carried out using the program R.

\section{Results}

In 2013, the enzymatic activity of soils in the study area was determined (Table 1). The specific activity of Sr-9o in soil varied from 25 to $1864 \mathrm{~Bq} / \mathrm{kg}$.

In the framework of radioecological research in 2015 , the area of research has been expanded, and, consequently, the range of specific radionuclide activity in the soil. 
TABLE 1: Enzymatic activity of soils contaminated with Sr-9o.

\begin{tabular}{|c|c|c|c|c|}
\hline $\begin{array}{c}\text { Specific activity } \\
\text { of Sr-90 in soil, } \\
\text { Bq / kg }\end{array}$ & $\begin{array}{l}\text { Urease activity, } \\
\mathrm{mg} \mathrm{NH}_{3} / 10 \mathrm{~g} \text { for } \\
24 \text { hours }\end{array}$ & $\begin{array}{l}\text { Invertase activity, } \\
\mathrm{mg} \mathrm{C}_{6} \mathrm{H}_{12} \mathrm{O}_{6} / \mathrm{g} / \text { day }\end{array}$ & $\begin{array}{l}\text { Dehydrogenase } \\
\text { activity, mg } \\
\text { TFF/10 g soil for } \\
24 \mathrm{~h}\end{array}$ & $\begin{array}{l}\text { Catalase activity, } \\
\mathrm{cm}^{3} \mathrm{O}_{2} / \mathrm{g} \text { * min }\end{array}$ \\
\hline 25 (control) & $1,93 \pm 0,28$ & $2,11 \pm 0,06$ & $2,10 \pm 1,15$ & $1,1 \pm 0,1$ \\
\hline 32 & $1,83 \pm 0,11$ & $2,53 \pm 0,28$ & $2,30 \pm 0,73$ & $1,2 \pm 0,2$ \\
\hline 33 & $1,80 \pm 0,18$ & $2,57 \pm 0,46$ & $1,93 \pm 0,59$ & $1,3 \pm 0,3$ \\
\hline 44 & $1,30 \pm 0,64$ & $2,47 \pm 0,28$ & $2,20 \pm 0,18$ & $1,7 \pm 0,2$ \\
\hline 86 & $1,13 \pm 0,74$ & $2,80 \pm 0,18$ & $2,37 \pm 0,38$ & $1,6 \pm 0,1$ \\
\hline 118 & $1,57 \pm 0,46$ & $2,63 \pm 0,28$ & $2,20 \pm 0,95$ & $2,3 \pm 1,1^{*}$ \\
\hline 155 & $1,63 \pm 0,70$ & $2,63 \pm 0,11$ & $2,47 \pm 1,33$ & $2,5 \pm 0,6^{*}$ \\
\hline 172 & $1,63 \pm 0,28$ & $3,20 \pm 0,18$ & $2,80 \pm 0,49$ & $3,6 \pm 1,1^{*}$ \\
\hline 173 & $2,20 \pm 0,55$ & $3,00 \pm 0,18$ & $2,37 \pm 0,38$ & $4,0 \pm 0,8 *$ \\
\hline 214 & $1,80 \pm 0,18$ & $3,33 \pm 0,28$ & $2,30 \pm 0,49$ & $3,2 \pm 1,7$ * \\
\hline 314 & $1,63 \pm 0,64$ & $2,57 \pm 0,28$ & $3,17 \pm 0,21$ & $4,8 \pm 1,5^{*}$ \\
\hline 331 & $1,77 \pm 0,28$ & $2,33 \pm 0,38$ & $3,10 \pm 0,18$ & $4,2 \pm 1,0$ * \\
\hline 353 & $1,63 \pm 0,28$ & $3,43 \pm 0,76$ & $1,87 \pm 0,42$ & $4,0 \pm 0,4^{*}$ \\
\hline 744 & $1,73 \pm 0,38$ & $3,97 \pm 0,18$ & $2,30 \pm 1,27$ & $7,0 \pm 0,1^{*}$ \\
\hline 847 & $1,50 \pm 0,37$ & $3,40 \pm 0,28$ & $2,00 \pm 0,49$ & $8,3 \pm 1,6 *$ \\
\hline 981 & $1,03 \pm 0,28$ & $3,43 \pm 0,18$ & $1,53 \pm 0,46$ & $8,4 \pm 1,7^{*}$ \\
\hline 1137 & $1,07 \pm 0,46$ & $1,70 \pm 0,18$ & $2,17 \pm 0,70$ & $11,7 \pm 6,4^{*}$ \\
\hline 1864 & $1,87 \pm 0,46$ & $2,27 \pm 0,28$ & $1,77 \pm 0,46$ & $21,3 \pm 6,4^{*}$ \\
\hline
\end{tabular}

The change in the catalase activity of soils with an increase in $\mathrm{Sr}-90$ in the soil from 19.7 \pm 11.1 to $1858 \pm 22 \mathrm{~Bq} / \mathrm{kg}$ is shown in Fig. 1 .

An analysis of the results of studies conducted in 2013 allows us to establish the following. There was no significant change in invertase activity with an increase in Sr-90 specific activity in soil from $24.7 \pm 5.6$ to $1864 \pm 9 \mathrm{~Bq} / \mathrm{kg}$ (Table 1 ). A high value (above the confidence level of 0.05 ) of $p$-value $=0.7643$ indicates a lack of reliable correlation, the correlation coefficient is 0.0395 . There were no statistically significant

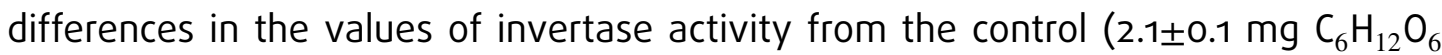
/g/day) on the basis of the Student's test. 


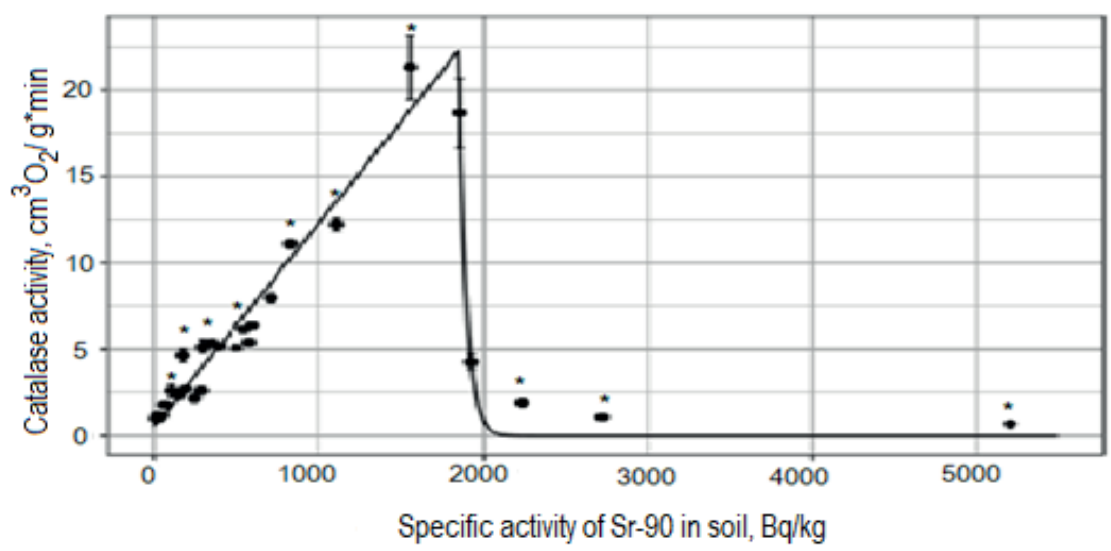

Figure 1: Change in catalase activity with increasing Sr-9o content in soilO6суждение.

Dehydrogenase activity of the soil varies within a narrow range of values from $1.5 \pm 0.5$ to $3.2 \pm 0.2 \mathrm{mg}$ TFF/10 g soil for 24 hours (Table 1). However, significant dif-

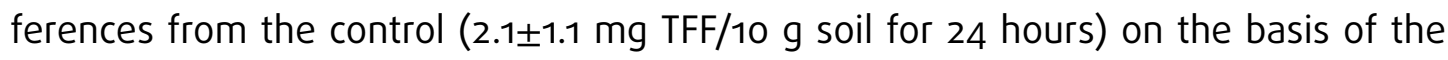
Student's test were not established for any of the experimental points, on the basis of which one can speak of the stability of dehydrogenase activity in the contamination of the terrestrial ecosystem of $\mathrm{Sr}-90$.

A similar situation is observed in the analysis of urease activity in soil (Table 1), which varies in the range from $0.6 \pm 0.3$ to $2.2 \pm 0.6 \mathrm{mg} \mathrm{NH}_{3} / 10 \mathrm{~g}$ for 24 hours. There were no significant differences in urease activity in the soils of local sites from the control value (1.9 $\pm 0.3 \mathrm{mg} \mathrm{NH} / 10 \mathrm{~g}$ for 24 hours) based on the Student's test

The change in the catalase activity of the soil is described by a reliable linear dependence $y=0.976 x+0.0098$ ( $p$-value $=2.2 e-16$ at a confidence level of 0.05 , the correlation coefficient is 0.962). On the basis of the Student's test, significant differences in the values of catalase activity for the studied regions from the control value $\left(1.1 \pm 0.1 \mathrm{~cm}^{3} \mathrm{O}_{2}\right.$ $/ g^{*}$ min) were established (Table 1 ). In this case, the catalase activity is stimulated with an increase in the specific activity in the soil from $118 \pm 16$ to $1864 \pm 9 \mathrm{~Bq} / \mathrm{kg}$.

Considering the significant change in catalase activity with an increase in Sr-90 content in the soil, an additional study of the catalase response to the radioactive contamination of the terrestrial ecosystem was carried out when the range of the study was expanded and, consequently, the specific activity range of the radionuclide in the soil. In this case, the change in catalase activity has a threshold character (Figure 1) with a threshold value of $21.3 \pm 5.9 \mathrm{~cm}^{3} \mathrm{O}_{2} / \mathrm{g}$ min.

With the specific activity of $\mathrm{Sr}-90$ in the soil from $19.7 \pm 11.1$ to $1858 \pm 22 \mathrm{~Bq} / \mathrm{kg}$, stimulation of catalase activity is noted. The increase in catalase activity from $0.9 \pm 0.3$ to $21.3 \pm 5.9 \mathrm{~cm}^{3} \mathrm{O}_{2} / \mathrm{g}$ min is linear and described by the equation of the form $y=0.482 \mathrm{x}$ 
+0.0118 ( $p$-value $<2.2 e-16$ ). A further increase in the specific activity of Sr-9o in the soil to $5,202 \pm 38 \mathrm{~Bq} / \mathrm{kg}$ leads to inhibition of catalase activity to $0.6 \pm 0.3 \mathrm{~cm}^{3} \mathrm{O}_{2} / \mathrm{g}^{\star} \mathrm{min}$ at a reference value of $0.9 \pm 0.3 \mathrm{~cm}^{3} \mathrm{O}_{2} / \mathrm{g}^{\star} \mathrm{min}$.

\section{Conclusion}

Based on the foregoing, it can be concluded that the activity of invertase, urease and dehydrogenase is resistant to radioactive contamination of Sr-9o soil in the range of specific radionuclide activity from $118 \pm 16$ to $1864 \pm 9 \mathrm{~Bq} / \mathrm{kg}$. Some researchers also noted the stability of the activity of the above soil enzymes to contamination of different genesis $[1,7]$.

It was revealed the sensitivity of catalase activity for radioactive contamination of $\mathrm{Sr}-90$ in the studied range of its specific activity. In this case, stimulation of activity is noted, and when the threshold value is reached, oppression is noted. It is known that the activity of catalase exhibits a different response to the technogenic effect. For example, there is a catalytic effect on catalase activity when oil products are introduced into the soil [6] and inhibitory - in soil radioactive contamination [10], at high concentrations of heavy metals in soil [5] and the level of dusting [9].

\section{References}

[1] Asvarova T.A. The effect of small doses of gamma radiation on the enzymatic activity of soils in Dagestan // Bulletin of TSU. 2013- T.18. - Issue 3 - P. 941-945 (in Russian)

[2] Bahrampour, T. Evaluation of soilbiological activityafter soilcontaminating by crudeoil // International Journal of Agriculture: Research and Review. 2012. - Vol. 6. - P. 671-679.

[3] Egorova E.I. Research of natural waters and soils by methods of biotesting. Textbook on summer practice (for students of 2-3 courses, studying in the specialty "Bioecology"). // Egorova E.I. - Obninsk: IATE. - 2004. - 52 p. (in Russian)

[4] Instruction : Procedure of radiochemical strontium-90 assessment in soil and plant samples, 1994. Instruction of Rosleskhoz of Russia from 05.09.1994 № 192. Moscow (in Russian).

[5] Kapralova O.A. Influence of urbanization on the ecological and biological properties of soils in Rostov-on-Don // Engineering Bulletin of the Don. - 2011. - T. 18. - No. 4. - P. 326-331 (in Russian) 
[6] Karimullin L.K., Petrov A.M. Enzymatic Activity of Soddy Podzolic Soils in Conditions of Long Oil Pollution // Bulletin of Kazan Technological University. 2014. - T. 17. - No. 10. - P. $122-124$ (in Russian)

[7] Korotchenko I.S., Kirienko N.N. Enzymatic activity of chernozem leached, contaminated with copper / / Bulletin of the State University. - 2014. - No. 3. - P. 104-110 (in Russian)

[8] Lavrentyeva G.V., Mirzeabasov O.A., Synzynys B.I. Monitoring of radioactive contamination of soils in the zone of impact of a regional near-surface repository of radioactive waste in the decommissioning stage // Radiation Biology. Radioecology. - 2017. - № 3. - P.279-285 (in Russian)

[9] Shashurin M.M. Enzymatic activity of soils and soil during chronic exposure to ecotoxicants of various nature in the conditions of Central and Southern Yakutia // Science and education. - 2012. - No 1. - P. 76-81 (in Russian)

[10] Shashurin MM, Shchelchkova MV, Zhuravskaya AN, Popov VI Influence of the increased natural background of growth on the enzymatic activity of soils and photosynthesis in alder shrub (Dushecia fruticosa) // Science and Education. - 2005. - No 2. - Vol. 38. - P. 23-27 (in Russian)

[11] Tazetdinova D.I. Antropogenic disturbing soil's microorganisms in Republic of Tatarstan / D.I. Tazetdinova, R.I. Tuhbatova, A.I. Akhmetova, F.E.A. Kabrera, F.K. Alimova //Materials of III international student conference «Topical aspects of Modern microbiology». - 2007. - P. 106.

[12] Zvyagintsev D.G. Biological activity of soils and scales for the evaluation of some of its indicators // Pochvovedenie. - 1978. - No 6. - P. 48-54 (in Russian) 